\title{
Penerapan Model Pembelajaran (PBI) Untuk Meningkatkan Kemampuan Pemecahan Masalah Matematis Siswa Pada Materi Kesebangunan
}

\author{
Chai Jan ${ }^{1}$, Citra Utami ${ }^{2}$, Nindy Citroresmi Prihatiningtyas ${ }^{3}$ \\ STKIP Singkawang, Singkawang, Indonesia \\ tjhinchaijan@gmail,com ${ }^{1}$, citrautami1990@gmail.com ${ }^{2}$, nindy.citroresmi@yahoo.com ${ }^{3}$
}

\section{Kata Kunci:}

PBI, Kemampuan Pemecahan

Masalah, Aktivitas Belajar,

Keterlaksanaan.

\begin{abstract}
ABSTRAK
Penelitian ini bertujuan untuk mengetahui penerapan PBI untuk meningkatkan kemampuan pemecahan masalah matematis siswa pada materi kesebangunan. Penelitian ini merupakan penelitian kuantitatif dengan menggunakan metode penelitian Pre-Experimental. Design yang digunakan ialah One-Group-Pretest-Posttest Design. Populasinya ialah semua siswa kelas IX SMPS Asoka Singkawang. Pengambilan sampel menggunakan teknik sampling jenuh. Pengumpulan data menggunakan tes kemampuan pemecahan masalah matematis, lembar observasi aktivitas belajar siswa, dan lembar observasi keterlaksanaan PBI. Teknik analisis data yang digunakan dalam penelitian ini yaitu $N$-Gain dan persentase. Hasil penelitian membuktikan bahwa (1) Gain ternormalisasi 0,6 kriteria sedang sehingga terdapat peningkatan kemampuan pemecahan masalah matematis siswa dengan menggunakan PBI (2) mean dari aktivitas belajar siswa tergolong sangat baik yaitu $91 \%$ (3) mean dari keterlaksanaan PBI tergolong sangat baik yaitu 95\%. Berdasarkan pemaparan di atas, penerapan model PBI untuk siswa kelas IX di SMPS Asoka Singkawang terdapat peningkatan pada kemampuan pemecahan masalah matematis siswa, aktivitas siswa tergolong sangat baik, dan keterlaksanaan model pembelajaran tergolong sangat baik.
\end{abstract}

\section{PENDAHULUAN}

Kemampuan pemecahan masalah merupakan kemampuan dasar yang harus dikuasai oleh siswa. Diperkuat oleh Widyantini dan Sigit (2010: 2) bahwa memahami konsep matematika, bernalar, menyelesaikan permasalahan, mengkomunikasikan ide, mempunyai perilaku menghargai faedah matematika merupakan tujuan dari pembelajaran matematika. Hasil atau output dari pembelajaran adalah siswa mampu menghadapi perubahan-perubahan tantangan dan permasalahan yang terjadi dalam kehidupan sehari-hari sehingga siswa mampu dan siap menyelesaikan berbagai persoalan. Kemampuan menyelesaikan permasalahan akan berkembang jika siswa sering dilibatkan dalam suatu permasalahan ketika pembelajaran berlangsung. Kemampuan pemecahan masalah matematis penting untuk dimiliki setiap siswa untuk mengembangkan keterampilannya. Menurut Polya (Rajagukguk 
Waminton, 2011), kemampuan pemecahan masalah harus meliputi empat indikator antara lain (1) memahami permasalahan; (2) menyusun rencana; (3) meyelesaikan permasalahan sesuai rencana yang disusun; (4) melakukan pengecekan kembali dan memberikan kesimpulan. Berdasarkan pengamatan dan interview dengan guru matematika di kelas IX SMPS Asoka, keterampilan siswa dalam menyelesaikan permasalahan masih di bawah kriteria ketuntasan minimal. Dibuktikan dengan memberikan dua soal prapenelitian diperoleh kemampuan dalam memahami permasalahan sebanyak $38,54 \%$, kemampuan menyusun rencana sebanyak 19,79\%, kemampuan menyelesaikan masalah sesuai rencana sebanyak $23,96 \%$, kemampuan melakukan pengecekan kembali dan memberikan kesimpulan sebanyak $16,67 \%$. Dari prapenelitian tersebut, menunjukkan pada kemampuan pemecahan masalah matematis siswa kelas IX SMPS Asoka Singkawang masih rendah. Rendahnya hasil siswa dalam menyelesaikan masalah yang terdapat pada soal disebabkan karena siswa belum paham bagaimana langkah membuat penyelesaian permasalahan dengan benar, ketidaktelitian melakukan perhitungan sesuai dengan rencana yang telah dibuat, dan lemahnya siswa dalam melakukan pengecekan kembali terhadap hasil jawaban yang diberikan, serta menuliskan kesimpulan. Menurut Buyung, B., \& Nirawati, R. (2018) bahwa proses pembelajaran matematika siswanya secara umum cenderung dalam kategori pasif.

Menurut Darmana (2013), salah satu penyebab rendahnya kemampuan pemecahan masalah matematis siswa adalah proses pembelajaran yang dilakukan masih konvensional sehingga belum mampu memfasilitasi tercapainya kemampuan pemecahan masalah matematis siswa. Dalam proses pembelajaran tentu tidak terlepas dari aktivitas yang dilakukan oleh siswa selama pembelajaran berlangsung. Belajar sangat dibutuhkan adanya aktivitas kerena jika tanpa aktivitas, proses pembelajaran tidak akan berlangsung dengan baik. Menurut Sardiman (2016: 100), aktivitas belajar ialah kegiatan yang bersifat jasmani maupun rohani di mana keduanya saling berhubungan satu sama lain. Dalam proses kegiatan belajar siswa akan menimbulkan perubahan-perubahan atau pembaharuan dalam tingkah laku atau kecakapan saat itulah aktivitas siswa itu terjadi. Jika dalam proses pembelajaran terlihat siswa aktif melakukan hal-hal positif yang berhubungan dengan materi pembelajaran seperti bertanya, menjawab pertanyaan yang diberikan, rasa ingin tahu yang tinggi, maka proses pembelajaran tersebut menunjukkan proses belajar siswa yang aktif. Dari observasi langsung yang peneliti lakukan, aktivitas belajar siswa masih pasif atau tidak aktif di SMPS Asoka Singkawang. Siswa cenderung menerima bahan atau materi pembelajaran yang dijelaskan oleh guru, siswa jarang bertanya dan kurang berusaha untuk menjawab pertanyaan baik yang diberikan oleh guru maupun oleh siswa lainnya. Siswa juga terlihat tidak terbiasa mengerjakan soal-soal yang tidak rutin, siswa cenderung menyerah dan kurang berusaha untuk menyelesaikan soal tersebut.

Berdasarkan situasi tersebut, dipandang perlu untuk mencari solusi yaitu sebuah model pembelajaran yang dapat membantu siswa dalam memahami langkah-langkah dalam proses pemecahan masalah dengan benar dan terarah, mampu mengembangkan kemampuan berpikir dan pemecahan masalah dalam kehidupan sehari-hari, serta dapat meningkatkan aktivitas siswa. Model pembelajaran yang dimaksud adalah PBI. Menurut Istarani (2014: 32), PBI ialah model pembelajaran student-center, di mana siswa belajar permasalahan yang berkaitan dengan kehidupan sehari-hari. PBI terdapat lima sintaks sebagai berikut: (1) orientasi pada masalah, (2) mengorganisasikan siswa untuk belajar, (3) membimbing penyelidikan individual maupun kelompok, (4) mengembangkan dan menyajikan hasil kerja, (5) menganalisis dan mengevaluasi proses pemecahan masalah. Penerapan PBI pada penelitian ini dihubungkan dengan materi kesebangunan. Materi kesebangunan juga merupakan salah satu materi yang dianggap sulit oleh siswa bila bentuk soal yang diberikan adalah soal tidak rutin yang memerlukan proses pemecahan masalah. Pada materi kesebangunan, siswa dihadapkan pada penggunaan konsep-konsep kesebangunan yang akan digunakan untuk menghitung panjang sisi dua segitiga sebangun dan penerapan konsep kesebangunan.

Berdasarkan paparan di atas, maka peneliti terdorong untuk melakukan penelitian dengan tujuan untuk mengetahui (1) Model PBI dapat meningkatkan kemampuan pemecahan masalah matematis siswa pada materi kesebangunan. (2) Aktivitas belajar siswa tergolong baik setelah mengimplementasikan 
PBI pada materi kesebangunan. (3) $P B I$ dapat terlaksana dengan baik pada materi kesebangunan untuk meningkatkan kemampuan pemecahan masalah matematis. Selain tujuan di atas, adapun manfaat dari penelitian ini antara lain menambah wawasan tentang model pembelajaran $P B I$, memberikan gambaran tentang penerapan model $P B I$ dalam proses pembelajaran matematika dan sebagai salah satu acuan model pembelajaran untuk meningkatkan kemampuan pemecahan masalah siswa

\section{METODE}

Penelitian ini termasuk dalam jenis penelitian Pre-Experimental dengan pendekatan kuantitatif. Rancangan penelitian berupa One-Group-Pretest-Posttest-Design. Sampel yang diambil dalam penelitian ini tidak random dan bertujuan untuk membandingkan keadaan sebelum diberi perlakukan dan sesudah diberi perlakukan yaitu dengan model $P B I$. Untuk mengetahui kemampuan pemecahan masalah matematis siswa pada materi kesebangunan maka dilakukan pretest (tes awal), setelah itu diberi perlakuan dalam jangka waktu tertentu, kemudian memberikan posttest (tes akhir). Berikut desain penelitian disajikan pada Tabel 1 .

Tabel 1 One-Group Pretest-Posttest Design

Keterangan:

\begin{tabular}{ccc}
\hline Pretest & Treatment & Posttest \\
\hline $\mathrm{O}_{1}$ & $\mathrm{X}$ & $\mathrm{O}_{2}$ \\
\hline
\end{tabular}

$\mathrm{O}_{1}=$ pretest (Sebelum diberi perlakukan)

$\mathrm{X}=$ perlakuan dengan $\mathrm{PBI}$

$\mathrm{O}_{2}=$ posttest (sesudah diberi perlakuan)

Dalam penelitian ini yang menjadi populasi adalah semua siswa kelas IX SMPS Asoka Singkawang Selatan Tahun Ajaran 2017/2018 yang terdiri dari satu kelas dengan jumlah 24 siswa. sampel yang digunakan sama dengan populasinya yaitu berjumlah 24 siswa karena SMPS Asoka hanya memiliki satu kelas pada kelas IX tahun ajaran 2017/2018. Teknik pengambilan sampel menggunakan teknik sampling jenuh. Hadi (2005: 205), Variabel penelitian ialah segala sesuatu yang akan dijadikan obyek pengamatan penelitian. Ada dua jenis variabel dalam penelitian ini yaitu independen (bebas) berupa model PBI. dan dependen (terikat) berupa kemampuan pemecahan masalah matematis dan aktivitas belajar siswa.

Teknik pengumpulan data dalam penelitian ini terdiri dari teknik pengukuran dan teknik observasi langsung. Instrumen terdiri dari (1) Soal essay untuk tes kemampuan pemecahan masalah matematis siswa sebelum diberi treatment dan setelah diberi treatment (2) Lembar observasi yang digunakan untuk mengukur tingkat aktivitas siswa dan keterlaksanaan model pembelajaran PBI. Lembar observasi disediakan beberapa indikator dari aktivitas dan keterlaksanaan model pembelajaran yang akan diamati. Analisis data yang akan dilakukan ialah menghitung rata-rata dari kedua treatment (pretest dan posttest), selanjutnya dengan perhitungan gain ternormalisasi untuk mengetahui data kemampuan pemecahan masalah siswa dengan rumus,

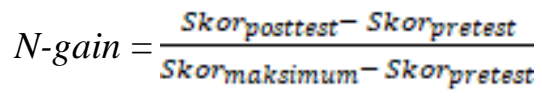

Selain data tes, data hasil observasi juga akan dianalisis. Untuk data observasi aktivitas siswa akan dihitung persentase frekuensi aktivitas belajar siswa dengan rumus,

$$
\mathrm{T}_{\mathrm{i}}=\frac{\text { Total skor dari setiapindikator yang diperoleh }}{\text { banyaknyaindikator yang diobservasi }} \times 100 \%
$$

sedangkan data keterlaksanaan akan dianalisis dengan menggunakan jumlah skor dengan rumus, 
Persentase Keterlaksanaan $=\frac{\text { jumlah skor seluruhindikator }}{\text { jumlah skor maksimal }} \times 100 \%$

\section{HASIL DAN PEMBAHASAN}

\section{A. Kemampuan Pemecahan Masalah Matematis Siswa}

Data yang disajikan dalam penelitian ini adalah data yang diperoleh dari hasil tes kemampuan pemecahan masalah matematis siswa pada materi kesebangunan. Adapun hasil tes kemampuan pemecahan masalah matematis siswa yaitu hasil pretest dan hasil posttest. Kedua tes ini mengacu pada indikator kemampuan pemecahan masalah matematis siswa yang terdiri dari indikator kemampuan memahami masalah, kemampuan menyusun rencana penyelesaian masalah, kemampuan menyelesaikan permasalahan sesuai dengan rencana, dan kemampuan melakukan pengecekan kembali serta memberikan kesimpulan. Berikut akan disajikan Tabel II tentang hasil perhitungan pretest dan posstest.

Tabel II Data Hasil Pretest dan Posttest

\begin{tabular}{ccccccccc}
\hline & \multicolumn{2}{c}{ Persentase Indikator Kemampuan Pemecahan Masalah } & & & & \\
& $\begin{array}{c}\text { Memahami } \\
\text { Masalah }\end{array}$ & $\begin{array}{c}\text { Menyusun } \\
\text { Rencana }\end{array}$ & $\begin{array}{c}\text { Melaksanakan } \\
\text { Rencana }\end{array}$ & $\begin{array}{c}\text { Mengecek } \\
\text { kembali }\end{array}$ & $\begin{array}{c}\text { Rata- } \\
\text { rata }\end{array}$ & $\begin{array}{c}\text { Standar } \\
\text { Deviasi }\end{array}$ & $\begin{array}{c}\text { Nilai } \\
\text { Terendah }\end{array}$ & $\begin{array}{c}\text { Nilai } \\
\text { Tertinggi }\end{array}$ \\
\hline Pretest & $61 \%$ & $38 \%$ & $30 \%$ & $31 \%$ & 40,28 & 6,66 & 27 & 40 \\
\hline Posttest & $82 \%$ & $80 \%$ & $69 \%$ & $69 \%$ & 74,58 & 21,14 & 50 & 100 \\
\hline
\end{tabular}

Berdasarkan Tabel II di atas dapat dilihat bahwa nilai rata-rata pretest lebih tinggi dibandingkan nilai posttest. Ini berarti ada peningkatan pada kemampuan pemecahan masalah matematis siswa setelah menggunakan $P B I$ pada materi kesebangunan. Adapun perhitungan hasil pretest dan posttest pada setiap indikator kemampuan pemecahan masalah matematis dapat dipaparkan sebagai berikut.

a. Pada indikator kemampuan memahami masalah, hasil pretest adalah $61 \%$ sedangkan hasil posttest adalah $82 \%$, meningkat $21 \%$.

b. Pada indikator kemampuan menyusun rencana penyelesaian, hasil pretest adalah $38 \%$ sedangkan hasil posttest adalah $80 \%$ meningkat $42 \%$.

c. Pada indikator kemampuan melaksanakan rencana penyelesaian, hasil pretest adalah $30 \%$ sedangkan hasil posttest adalah 69\%, meningkat 39\%.

d. Pada indikator kemampuan melakukan pengecekan kembali dan memberikan kesimpulan, hasil pretest adalah $31 \%$ sedangkan hasil posttest adalah $69 \%$, meningkat $38 \%$.

Untuk memperkuat hasil penelitian dan mengukur peningkatan kemampuan pemecahan masalah matematis siswa, dilakukan perhitungan $\mathrm{N}$-gain terlihat pada Tabel III.

Tabel III Nilai Gain Ternormalisasi

\begin{tabular}{llll}
\hline \multicolumn{4}{c}{ Nilai Rata-rata } \\
\hline Pretest & Posttest & $N$-gain & Kategori \\
\hline 40,3 & 74,6 & 0,6 & Sedang \\
\hline
\end{tabular}

Adapun data $\mathrm{N}$-gain setiap siswa dikategorikan sesuai dengan kategori $\mathrm{N}$-gain diperoleh sebanyak 10 siswa dengan kategori tinggi, 7 siswa dengan kategori sedang, dan 7 siswa kategori rendah. Berdasarkan hasil perhitungan dengan menggunakan rumus $\mathrm{N}$-gain maka diperoleh nilai 0,6 dengan kriteria sedang, sehingga dinyatakan setelah diberi treatment $P B I$ terdapat peningkatan kemampuan pemecahan masalah matematis siswa.

Faktor yang menyebabkan meningkatnya kemampuan pemecahan masalah matematis siswa dengan menggunakan model $P B I$ adalah rangkaian kegiatan pembelajaran yang menekankan siswa untuk berpikir dan menyelesaikan permasalahan-permasalahan yang berkaitan dengan pemecahan masalah dengan menggunakan sintaks model PBI. Pada tahap pertama yaitu melakukan orientasi pada masalah 
sudah mampu memfasilitasi siswa dalam memahami permasalahan yang terdapat pada soal. Tahap kedua yaitu mengorganisasikan siswa untuk belajar sudah mampu memfasilitasi siswa belajar secara berkelompok untuk berdiskusi dan merencanakan penyelesaian. Pada tahap ketiga yaitu membimbing penyelidikan secara individual atau kelompok sudah mampu memfasilitasi siswa untuk bertanya bila terdapat permasalahan yang belum dipahami dalam proses menyusun rencana penyelesaian. Pada tahap keempat yaitu mengembangkan dan menyajikan hasil karya sudah mampu memfasilitasi siswa dengan bantuan LKS, siswa berdiskusi kemudian mempresentasikan hasil kerja kelompok di depan kelas. Pada tahap kelima yaitu menganalisis dan mengevaluasi proses pemecahan masalah sudah mampu memfasilitasi siswa dalam melakukan refleksi dan evaluasi selama proses penyelidikan hingga menyajikan hasil, siswa dapat melakukan pengecekan kembali dan memberikan kesimpulan dengan benar. Dengan demikian, kemampuan pemecahan masalah matematis siswa mengalami peningkatan setelah menerapkan model pembelajaran $P B I$ pada materi kesebangunan Hal ini sejalan dengan penelitian yang dilakukan oleh Darmana (2013) "pengaruh Model PBI Terhadap Kemampuan Pemecahan Masalah Dalam Pembelajaran Matematika" menunjukkan bahwa skor kemampuan pemecahan masalah pembelajaran matematika pada siswa yang mengikuti pembelajaran konvensional cenderung rendah daripada pembelajaran dengan model $P B I$.

\section{B. Aktivitas Belajar Siswa}

Dari hasil observasi oleh tiga pengamat/observer menyatakan bahwa siswa sangat aktif dalam mengikuti pembelajaran dari awal pembelajaran sampai akhir pembelajaran dengan menggunakan model pembelajaran $P B I$. Berikut hasil rekapitulasi pengamatan aktivitas belajar siswa selama dua kali pertemuan terlihat pada Tabel IV di bawah ini.

Tabel IV Rekapitulasi Aktivitas Belajar Siswa

\begin{tabular}{cccc}
\hline $\begin{array}{c}\text { Pertemuan } \\
\text { ke- }\end{array}$ & $\begin{array}{c}\text { Rata-rata setiap } \\
\text { pertemuan }\end{array}$ & $\begin{array}{c}\text { Rata-rata persentase } \\
\text { aktivitas belajar }\end{array}$ & Kriteria \\
\hline I & $90 \%$ & $91 \%$ & Sangat baik \\
\hline II & $92 \%$ & $91 \%$ & \\
\hline
\end{tabular}

Berdasarkan Tabel IV di atas dapat dilihat mean dari aktivitas pertemuan pertama sebesar $90 \%$ dan pertemuan kedua sebesar 92\%, sehingga mean dari kedua pertemuan sebesar $91 \%$ yaitu kriteria sangat baik. Berarti ada peningkatan sebesar $2 \%$ dari tatap muka pertama dan kedua setelah menerapkan $P B I$. Berikut persentase setiap indikator aktivitas belajar siswa (1) mean $92 \%$ kriteria sangat baik untuk Visual Activities, (2) mean $87 \%$ kriteria sangat baik untuk Oral Activities, (3) mean $91 \%$ kriteria sangat baik untuk Listening Activities, (4) mean 91\% kriteria sangat baik untuk Writing Activies, (5) mean 95\% kriteria sangat baik untuk Mental Activities, (6) mean 94\% kriteria sangat baik untuk emotional Activities. Data dari hasil observasi aktivitas belajar siswa menunjukkan bahwa aktivitas belajar siswa dengan menggunakan model pembelajaran $P B I$ tergolong sangat baik. Dengan menggunakan sintaks model pembelajaran $P B I$, proses pembelajaran didominasi oleh siswa. Pemilihan model pembelajaran ini efektif sehingga menghasilkan aktivitas belajar yang baik.

Pertama, melakukan orientasi pada masalah yaitu siswa terlihat aktif saat melakukan pengamatan terhadap suatu masalah yang diberikan, dapat memperhatikan teman sekelompoknya saat diskusi berlangsung, dan merumuskan masalah saat berdiskusi. Kedua, mengorganisasikan siswa untuk belajar yaitu siswa terlihat aktif saat diskusi berlangsung, mencatat hal-hal penting yang disampaikan guru ataupun dari hasil diskusi, dan siswa antusias dalam menjawab pertanyaan. Ketiga, membimbing penyelidikan individual maupun kelompok yaitu siswa terlihat sangat semangat untuk mengikuti pembelajaran, siswa mendengarkan percakapan guru ataupun teman lainnya saat proses pembimbingan, siswa bersama-sama memecahkan masalah berdasarkan pendapat yang dikemukakan, dan dapat mengerjakan tugas yang diberikan guru. Keempat, mengembangkan dan menyajikan hasil kerja yaitu siswa dapat mencatat laporan hasil kerja kelompok, mempresentasikan hasil kerja kelompok dan tetap tenang/tidak gugup dalam memecahkan masalah yang diberikan. Kelima, 
menganalisis dan mengevaluasi pemecahan masalah yaitu siswa memperhatikan presentasi kelompok dan memberikan pertanyaan/tanggapan terhadap apa yang disampaikan oleh guru, siswa tidak menunjukkan rasa bosan dalam pembelajaran dan siswa mencatat kesimpulan atau rangkuman materi yang diberikan. Dengan demikian, penggunaan model pembelajaran $P B I$ pada materi kesebangunan sudah efektif karena siswa memberikan respon yang positif selama pembelajaran sehingga dapat disimpulkan bahwa aktivitas belajar siswa tergolong sangat baik setelah menerapkan model pembelajaran PBI pada materi kesebangunan di kelas IX SMPS Asoka Singkawang. Sejalan dengan penelitian dari Prihatiningtyas dan Nurhayati (2017) yang menyatakan bahwa hasil pengamatan aktivitas belajar siswa dalam mengikuti pembelajaran, siswa terlihat aktif dan perilaku ditunjukkan siswa melalui aktivitas bertanya yang baik kepada guru maupun teman yang lain, siswa juga terlihat serius dalam mengikuti setiap peragaan yang disajikan oleh guru. Diperkuat juga penelitian oleh Nuryanti (2018), bahwa selama tiga kali pertemuan menunjukkan aktivitas guru dan peserta didik selama mengikuti pelajaran menggunakan model pembelajaran $P B I$ mengalami peningkatan pada tiap pertemuannya dengan rata-rata aktivitas guru dan peserta didik masing-masing sebesar $82 \%$ dengan kategori sangat baik dan $73 \%$ dengan kategori baik.

\section{Keterlaksanaan PBI}

Data keterlaksanaan $P B I$ diperoleh dari pengamatan dengan menggunakan lembar observasi keterlaksanaan yang ada di dalam RPP dengan menggunakan PBI pada materi kesebangunan. Dari hasil pengamatan dapat dinyatakan bahwa model pembelajaran $P B I$ dapat terlaksana dengan sangat baik, secara keseluruhan indikator keterlaksanaan dapat terpenuhi dengan sangat baik. Indikator keterlaksanaan yang dianalisis berdassarkan sintaks $P B I$ yang dilakukan sebanyak dua kali. Adapun hasil rekapitulasi keterlaksanaan model pembelajaran $P B I$ yang ditampilkan Gambar I di bawah ini.

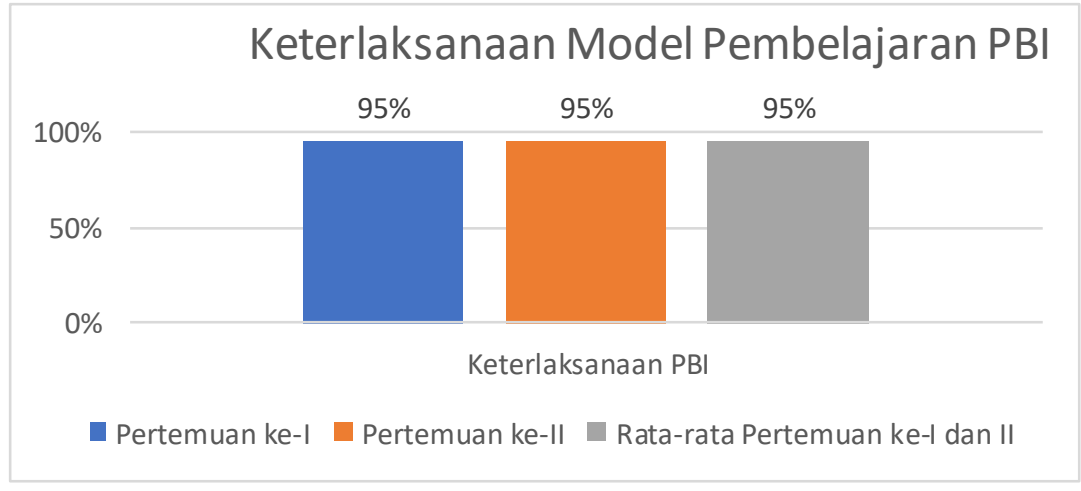

Gambar I Diagram Batang Keterlaksaan PBI

Berdasarkan Gambar I di atas, persentase frekuensi keterlaksanaan sebesar 95\% dengan kriteria sangat baik. Kemudian melihat nilai rata-rata keseluruhan persentase frekuensi keterlaksanaan pertemuan pertama dan pertemuan kedua sebesar 95\%, maka keterlaksanaan model pembelajaran PBI dikategori sangat baik.

Selama proses pembelajaran, guru melakukan langkah-langkah pengajaran sesuai dengan RPP yang telah dibuat di mana langkah-langkah RPP ini memuat sintaks model pembelajaran PBI. Pertama, orientasi pada masalah yaitu guru membagikan LKS kepada setiap kelompok kemudian guru meminta siswa untuk memahami permasalahan yang terdapat pada LKS tersebut. Kedua, mengorganisasikan siswa untuk belajar yaitu pada saaat diskusi berlangsung siswa merencanakan penyelesaian masalah. Ketiga, membimbing proses penyelidikan individual atau kelompok, siswa dapat bertanya bila ada yang belum dipahami selama proses diskusi bila dalam satu kelompok tesebut ada yang tidak dimengerti. Keempat, mengembangkan dan menyajikan hasil kerja yaitu siswa menyelesaikan permasalahan secara berkelompok dan mempresentasikan hasilnya di depan kelas melalui perwakilan kelompok. Kelima, menganalisis dan mengevaluasi proses pemecahan masalah yaitu melakukan refleksi dan melakukan pengecekan kembali serta memberikan kesimpulan. Dengan demikian, 
keterlaksanaan model pembelajaran $P B I$ pada materi kesebangunan untuk meningkatkan kemampuan pemecahan masalah matematis siswa tergolong sangat baik karena siswa dapat mengikuti pembelajaran dengan baik, terlihat aktif, dan mampu menyelesaikan masalah yang berhubungan dengan pemecahan masalah pada materi kesebangunan yang diterapkan di kelas IX SMPS Asoka Singkawang. Sejalan dengan penelitian yang dilakukan oleh Khotimah, Utami, dan Prihatiningtyas (2018) yang menunjukkan bahwa pengamatan keterlaksanaan pada pertemuan pertama yang memuat lima belas kegiatan memperoleh persentase sebesar $67,5 \%$, sedangkan pada pertemuan kedua yang memuat lima belas kegiatan memperoleh persentase sebesar $72,5 \%$ sehingga rata-rata persentase dari dua kali pertemuan sebesar $70 \%$ yang dikategorikan baik. Diperkuat dengan penelitian yang dilakukan juga oleh Safitri (2017) bahwa proses pembelajaran dengan menggunakan model PBI berbasis ICARE dapat berpengaruh positif terhadap kemampuan pemecahan masalah siswa di mana hasil $N$-gain 0,32 kategori sedang dan hasil observasi aktivitas siswa terinterpretasi sangat baik.

\section{KESIMPULAN DAN SARAN}

Secara umum dari hasil penelitian dan pembahasan disimpulkan bahwa kemampuan pemecahan masalah matematis siswa mengalami peningkatan dengan menggunakan model pembelajaran $P B I$ pada materi kesebangunan di kelas IX SMPS Asoka Singkawang tahun pelajaran 2017/2018. Secara khusus disimpulkan (1) Terdapat peningkatan kemampuan pemecahan masalah matematis siswa sesudah menggunakan PBI pada materi kesebangunan kelas IX SMPS Asoka Singkawang meningkat dengan kriteria sedang. (2) Aktivitas belajar siswa tergolong sangat baik sesudah menggunakan $P B I$ pada materi kesebangunan kelas IX SMPS Asoka Singkawang yang sudah dilaksanakan sebanyak dua kali pertemuan dengan kriteria sangat baik. (3) Keterlaksanaan $P B I$ pada materi kesebangunan yang sudah dilaksanakan sebanyak dua kali pertemuan untuk meningkatkan kemampuan pemecahan masalah matematis siswa tergolong sangat baik.

Adapun saran yang dapat disampaikan berdasarkan hasil penelitian antara lain model $P B I$ merupakan salah satu alternatif model pembelajaran untuk mengukur kemampuan pemecahan masalah matematis siswa karena setiap langkah atau sintaks pada $P B I$ mengarah pada pemecahan masalah, selain itu juga dapat meningkatkan aktivitas belajar siswa. Tidak hanya digunakan untuk materi kesebangunan, model pembelajaran $P B I$ juga diharapkan dapat digunakan pada materi lain yang memerlukan proses pemecahan masalah.

\section{DAFTAR PUSTAKA}

Buyung, B., \& Nirawati, R. (2018). Pengaruh Karakter Kerja Keras Terhadap Kemampuan Literasi Matematis Siswa Melalui Model Discovery Learning. JPMI (Jurnal Pendidikan Matematika Indonesia), 3(1), 21-25.

Darmana, R., Sedanayasa, dan Antari, M. (2013). Pengaruh Model PBI Terhadap Kemampuan Pemecahan Masalah Dalam Pembelajaran Matematika. Mahasiswa S1 Jurusan PGSD. Jurnal Penelitian. Diakses 11 September 2015.

Hadi, A dan Haryono (2005). Metodologi Penelitian Pendidikan. Bandung: Pustaka Setia.

Istarani. (2011). 50 Tipe Pembelajaran Kooperatif. Medan: CV Media.

Khotimah, N., Utami, C., dan Prihatiningtyas, C.N. (2018). Penerapan Model Learning Cycle 7E Untuk Meningkatkan Kemampuan Literasi Matematika Kelas VIII Pada Materi Prisma. Jurnal Pendidikan Matematika Indonesia, 3(1), 15-20.

Nuryanti, Ana. (2018). Penerapan Model Pembelajaran Problem Based Instruction (PBI) Untuk Meningkatkan Penguasaan Konsep Peserta Didik Pada Materi Gerak Lurus. Jurnal Penelitian. Diakses 17 September 2020.

Prihatiningtyas, C.N., dan Nurhayati. (2017). Penerapan Model Pembelajaran Means Ends Analysis Untuk Meningkatkan Kemampuan Pemecahan Masalah Matematis Siswa. Jurnal Pendidikan Matematika Indonesia, 2 (1), 13-18. 
Rajagukguk, Waminton. (2011). Upaya Meningkatkan Kemampuan Pemecahan Masalah Matematika Siswa Dengan Penerapan Teori Belajar Bruner Pada Pokok Bahasan Trigonometri di Kelas X SMA Negeri 1. Jurnal Penelitian Tindakan Kelas. Diakses 25 Februari 2015.

Safitri, A.T. (2017). Penerapan Model Pembelajaran Problem Based Instruction (PBI) Berbasis ICARE Untuk Meningkatkan Kemampuan Pemecahan Masalah Siswa. Jurnal Penelitian. Diakses 17 September 2020.

Sardiman. (2016). Interaksi \& Motivasi Belajar Mengajar. Jakarta: PT RajaGrafindo Persada. Sembiring, Suwah. (2012). Matematika untuk SMP Kelas IX. Bandung: Yrama Widya.

Widyantini dan Sigit. (2010). Pemanfaatan Alat Peraga Dalam Pembelajaran Matematika SMP Diklat SMP Jenjang Dasar. Yogyakarta. 